\title{
A Integração da Reumatologia Brasileira
}

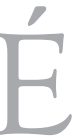

com grande satisfação e orgulho que, como editores da RBR, temos observado o crescente empenho de nossos colegas reumatologistas no definitivo papel da RBR como um importante veículo de divulgação do que se faz de melhor em nosso país. Assim, a divulgação do resultado de projetos originais em nosso meio, como, por exemplo, o artigo da Dra. Lima et al.$^{(1)}$, da Bahia, sobre a difícil e laboriosa dosagem sérica de adenosina deaminase no LES. O artigo do Dr. Fernandez et al. ${ }^{(2)}$ de Goiás, que atenta para a importância da pesquisa de clamídia como possível agente desencadeador da atividade inflamatória em algumas das doenças reumáticas, como as espondiloartropatias e a artrite reumatóide. Especial destaque merece o artigo original da Dra. Bisotto et al. ${ }^{(3)}$, do Rio Grande do Sul, no qual avaliou-se os parâmetros nutricionais na artrite idiopática juvenil. Para tal artigo gostaríamos de enfatizar que os autores tiveram dificuldades em comparar seus resultados com a população normal brasileira, pela total e absoluta falta de dados sobre o assunto. Se alguém algum dia avaliou o padrão nutricional normal em nosso meio, não o divulgou, ou se o fez, não se utilizou dos meios eficientes para tanto. Assim, tomando este último artigo como exemplo, gostaríamos de ressaltar que um dos primordiais papéis de veículos científicos oficiais, como a nossa Revista Brasileira de Reumatologia, é justamente divulgar assuntos de interesse nacional e que pouco interessam a editores estrangeiros. Se chamarmos a atenção

\section{REFERÊNCIAS}

1. Lima I, Néri F, Santiago MB: Dosagem Sérica de Adenosina Deaminase em Lúpus Eritematoso Sistêmico: Ausência de Associação com Atividade de Doença. Rev Bras Reumatol 45: 273-9.

2. Fernandez RN, Ximenes AC, Alves MFC: Detecção do DNA de "Chlamydia trachomatis" em Espondiloartropatias e Artrite Reumatóide. Rev Bras Reumatol 45: 280-90. para nossos problemas de saúde, com certeza teremos mais argumentos na divisão dos recursos destinados à saúde. Assim, este seria um dos primeiros chamados de nossos especialistas a uma melhor divulgação dos problemas associados à nossa especialidade e que tanto afligem a nossa população. Ainda dentro deste espectro, sentimo-nos muito honrados com a carta aos editores enviada pelo nosso próximo presidente, o Dr. Fernando Neubarth ${ }^{(4)}$, que sugere uma maior coesão de nossa comunidade científica, para a utilização deste nosso veículo de comunicação para o engrandecimento de nossa pequena mas expressiva legião de colaboradores. E é lógico que quando falamos de colaboradores, não podemos deixar de elogiar, agradecer e enaltecer o brilhante serviço prestado por nossos revisores, que de forma altruísta e desinteressada têm contribuído sobremaneira no refinamento de nossos artigos, que com suas cuidadosas revisões vem proporcionando esclarecimentos e ensinamentos não só a jovens autores - que de forma crescente e louvável estão à frente de grande parte dos trabalhos enviados a nossa revista -, como também a pesquisadores mais experientes com sugestões construtivas ao aprimoramento de nosso material científico.

Obrigado a todos os nossos colaboradores e leitores.

Lais V. Lage e Roger A. LeVy Editores da RBR

3. Bisotto LS, Xavier RM, Machado SH, Bredemeier M, Brenol JCT: Impacto da Atividade Inflamatória e Uso de Glicocorticóide nas Variáveis Nutricionais da Artrite Idiopática Juvenil. Rev Bras Reumatol 45: 291-300.

4. Neubarth F: Carta aos editores. Rev Bras Reumatol 45(5): XXIII. 